\title{
THE EFFECT OF BUFFER LOADING UPON AMMONIUM EXCRETION IN THE DOG*
}

\author{
BY NORMAN BANK $\dagger$ \\ (From the Department of Medicine, New York Medical College, New York, N. Y.)
}

(Submitted for publication October 7, 1960; accepted November 10, 1960)

According to present concepts, urinary ammonium and titratable acid represent, quantitatively, hydrogen ions eliminated from the body by the kidney (1). Although it is known that titratable acid excretion depends upon the amount of buffer in the urine and urine $\mathrm{pH}(2)$, and that ammonium excretion in man and $\operatorname{dog}$ is determined primarily by urine $\mathrm{pH}(3-6)$, it is not clear whether there is any fundamental interdependence of these two moieties of acid excretion. In previous studies where both were measured (7-10), variations in urine acidity could have affected either ammonium or titratable acid excretion predominantly and could thus have obscured a significant underlying relationship between the two.

In the present experiments in dogs, titratable acid excretion was increased progressively by intravenous sodium phosphate loading, and the effect on ammonium excretion was studied under conditions of relatively constant urine $\mathrm{pH}$. Because of evidence that ammonium excretion is limited by rate of intracellular $\mathrm{NH}_{3}$ production in acid but not in alkaline urine (4), experiments were carried out in both urine $\mathrm{pH}$ ranges. In one group of animals, ammonium excretion was stimulated by prior induction of metabolic acidosis. It was found that in each of these experimental situations, ammonium excretion was entirely independent of the buffer content of the urine and the rate of titratable acid excretion. Although these observations do not allow any conclusions concerning the intimate nature of ammonium transport into the urine, they suggest that the mechanism regulating ammonium excretion in the dog may be dissociated from total hydrogen ion excretion and those factors that determine the

* Supported by grants from the Life Insurance Medical Research Fund and the National Heart Institute, Bethesda, Md.

$\dagger$ Investigator of the Health Research Council of the City of New York. Present address: Department of Medicine, New York University Medical Center, New York, N. Y. magnitude of $\mathrm{Na}^{+}-\mathrm{H}^{+}$exchange. They also support the view that the availability of hydrogen ions does not ordinarily constitute a limiting factor in the accumulation of ammonium in the urine.

\section{METHODS}

Fifteen experiments were carried out on 15 female mongrel dogs weighing between 10 and $22 \mathrm{~kg}$. In 10 experiments, systemic acid-base balance was normal and the urine $\mathrm{pH}$ was adjusted to either an acid or a more alkaline range by infusion of sodium ferrocyanide or sodium chloride. In the other 5 experiments, ammonium excretion was augmented by inducing metabolic acidosis for 5 to 7 days prior to the acute experiment. Titratable acid excretion was increased progressively by infusion of sodium phosphate in concentrations calculated to deliver sodium at the same rate as during the preceding control periods. Anesthesia was induced by intravenous chloralose, $100 \mathrm{mg}$ per $\mathrm{kg}$, as a 1.5 per cent solution in 4 per cent dextrose. Additional small amounts were given as required.

Group I: Normal acid-base balance. Five animals were maintained on a salt-free diet for 7 to 10 days. After induction of anesthesia, a solution containing 30 mmoles per $\mathrm{L}$ of $\mathrm{Na}_{4} \mathrm{Fe}(\mathrm{CN})_{6}$ was administered at 4.5 $\mathrm{ml}$ per minute by means of a Bowman infusion pump. When a constant urine flow had been established, several timed urine collections were made. The solution was then replaced by one containing the following in millimoles per liter: $\mathrm{Na}_{2} \mathrm{HPO}_{4}, 48 ; \mathrm{NaH}_{2} \mathrm{PO}_{4}, 12 ; \mathrm{Na}_{4}-$ $\mathrm{Fe}(\mathrm{CN})_{6}$, 3. Fifteen to 45 minutes after starting this infusion, urine was collected for 5 additional periods.

The other 5 animals in this group were maintained on a normal diet. Sodium chloride, 135 mmoles per L, was infused and after a constant urine flow had been established, several urine specimens were collected. A sodium phosphate infusion was then begun and additional urine specimens obtained.

Group II: Chronic metabolic acidosis. Five dogs were fed $8 \mathrm{~g}$ of ammonium chloride daily for 5 to 7 days prior to the acute experiment. In order to assure a markedly acid urine, $0.1 \mathrm{~N} \mathrm{HCl}$ in 4 per cent dextrose was administered for 30 to 60 minutes at the start of each experiment. Control urine specimens were collected during sodium ferrocyanide infusion. A solution containing 50 mmoles per $\mathrm{L}$ of $\mathrm{Na}_{2} \mathrm{HPO}_{4}$ and 25 mmoles per $\mathrm{L}$ of $\mathrm{NaH}_{2} \mathrm{PO}_{4}(\mathrm{pH}$ 7.1) was then substituted for the ferrocyanide and additional urine collections were ob- 
tained. Dextrose was added to each solution to adjust the final osmolarity to between 240 and 270 .

Urine was collected through an indwelling catheter and the bladder emptied by manual compression at the end of each period. $\mathrm{pH}$ was determined on mid-point aliquots collected without exposure to air. Heparinized blood samples were collected from the femoral artery for determination of $\mathrm{pH}$ and $\mathrm{CO}_{2}$ content.

Urine and blood $\mathrm{pH}$ were determined at $37^{\circ} \mathrm{C}$ without exposure to air, with a Cambridge model $\mathrm{R} \mathrm{pH}$ meter. Plasma $\mathrm{CO}_{2}$ content was determined manometrically by the method of Van Slyke and Neill (11). Urine ammonium was measured by the method of Folin and Bell (12) and inorganic phosphorus by that of Fiske and Subbarow (13). Sodium and potassium were determined by flame photometry with lithium as an internal standard. Chloride was measured by titration with silver nitrate, by a potentiometric method (14). Titratable acid was calculated from urine phosphate, urine $\mathrm{pH}$ and blood $\mathrm{pH}$. (During phosphate loading, organic buffers contribute only a relatively small amount to total titratable acid excretion.) In this calculation, the $\mathrm{pK}_{2}^{\prime}$ of phosphoric acid was taken to be 6.8 in blood and in urine when urine $\mathrm{pH}$ was below 6.0. It has been shown that significant deviations in $\mathrm{pK}_{2}^{\prime}$ due to variations in urinary ionic strength may introduce appreciable errors in estimation of titratable acid when urine $\mathrm{pH}$ is above 6.0. In such urines, $\mathrm{pK}_{2}^{\prime}$ was calculated from an estimated ionic strength. An arbitrary addition of 0.025 was made to the ionic strength estimate to account for organic acids, bicarbonate, calcium, and other unmeasured ions. The theoretical considerations and methods of calculation of $\mathrm{pK}_{2}^{\prime}$ from ionic strength have been previously described (15).

\section{RESULTS}

Group I. The results of one of the experiments in this group are shown in detail in Table $I$. During the infusion of sodium ferrocyanide, urine
$\mathrm{pH}$ varied between 5.04 and 5.30 and ammonium excretion between 27 and 30 moles per minute. With the subsequent administration of sodium phosphate, titratable acid excretion increased from 1 to $100 \mu \mathrm{Eq}$ per minute, and urine $\mathrm{pH}$ rose only about 0.3 unit. In spite of the marked increase in buffer content of the urine and titratable acid excretion, ammonium excretion was essentially unaltered. Blood $\mathrm{pH}$ and bicarbonate were in the low-normal range and did not change appreciably during the course of the experiment.

The results of the five experiments in which aciduria was induced by ferrocyanide infusion are shown in Figure 1 as solid circles. The circle marked by an asterisk represents the average ammonium and titratable acid values for all periods during sodium ferrocyanide administration. Urine $\mathrm{pH}$ values were between 4.8 and 5.8 in almost all instances and in individual experiments varied by no more than 0.6 unit. It is clear that increases in titratable acid excretion up to $133 \mu \mathrm{Eq}$ per minute had no discernible effect upon ammonium excretion. Sodium excretion remained essentially constant in three experiments, while in the other two there was a moderate fall when the ferrocyanide solution was replaced by phosphate. Blood $\mathrm{pH}$ and bicarbonate values were within normal limits during control periods and showed small increases during phosphate loading.

In Table II are shown the results of an experiment in which urine $\mathrm{pH}$ was more alkaline, owing to the administration of sodium chloride.

TABLE I

The effect of a sodium phosphate infusion upon ammonium excretion

\begin{tabular}{|c|c|c|c|c|c|c|c|c|c|c|c|c|}
\hline \multicolumn{10}{|c|}{ Urine } & \multicolumn{3}{|c|}{ Plasma } \\
\hline Time & Flow & $\mathrm{Na}$ & $\mathbf{K}$ & $\mathrm{Cl}$ & $\mathrm{NH}_{4}{ }^{+}$ & $\mathbf{P}$ & $\mathrm{pH}$ & TA & $\mathrm{TA}+\mathrm{NH}_{4}{ }^{+}$ & $\mathrm{pH}$ & $\mathrm{HCO}_{3}$ & $\mathrm{pCO}_{2}$ \\
\hline $\min$ & $\mathrm{ml} / \mathrm{min}$ & $\underset{\text { min }}{\mu \text { moles }}$ & $\underset{\text { min }}{\mu \text { moles }}$ & $\underset{\min }{\operatorname{\mu moles}}$ & $\underset{\text { min }}{\mu \text { moles }}$ & $\underset{\text { min }}{\operatorname{\mu moles}}$ & & $\underset{\min }{\mu E q /}$ & $\underset{\min }{\mu E q /}$ & & mmoles $/ L$ & $m m \mathrm{Hg}$ \\
\hline 0 & \multicolumn{12}{|c|}{ Infusion: $\mathrm{Na}_{4} \mathrm{FE}(\mathrm{CN})_{6}, 30 \mathrm{mmoles} / \mathrm{L}$; dextrose, $110 \mathrm{mmoles} / \mathrm{L}$ at $4.5 \mathrm{ml} / \mathrm{min}$} \\
\hline $\begin{array}{c}65-85 \\
85-100 \\
100-115 \\
115-130 \\
130-145\end{array}$ & $\begin{array}{l}1.5 \\
1.7 \\
1.7 \\
2.2 \\
3.1\end{array}$ & $\begin{array}{l}261 \\
346 \\
294 \\
273 \\
357\end{array}$ & $\begin{array}{l}78 \\
87 \\
67 \\
62 \\
69\end{array}$ & $\begin{array}{l}4 \\
4 \\
3 \\
2 \\
5\end{array}$ & $\begin{array}{l}29 \\
28 \\
30 \\
27 \\
30\end{array}$ & $\begin{array}{l}2 \\
2 \\
2 \\
1 \\
1\end{array}$ & $\begin{array}{l}5.16 \\
5.24 \\
5.30 \\
5.04 \\
5.29\end{array}$ & $\begin{array}{l}1 \\
1 \\
1 \\
1 \\
1\end{array}$ & $\begin{array}{l}30 \\
29 \\
31 \\
28 \\
31\end{array}$ & 7.30 & 19.8 & $\begin{array}{l}42.5 \\
41.4\end{array}$ \\
\hline 147 & \multicolumn{12}{|c|}{$\begin{array}{l}\text { Infusion: } \mathrm{Na}_{2} \mathrm{HPO}_{4}, 48 \mathrm{mmoles} / \mathrm{L} ; \mathrm{NaH}_{2} \mathrm{PO}_{4}, 1 \\
\text { mmoles } / \mathrm{L} \text { at } 4.5 \mathrm{ml} / \mathrm{min}\end{array}$} \\
\hline $\begin{array}{l}185-200 \\
200-215 \\
215-230 \\
230-245 \\
245-260\end{array}$ & $\begin{array}{l}2.7 \\
2.6 \\
2.2 \\
2.1 \\
2.3\end{array}$ & $\begin{array}{l}284 \\
263 \\
214 \\
212 \\
223\end{array}$ & $\begin{array}{l}66 \\
63 \\
56 \\
59 \\
59\end{array}$ & $\begin{array}{l}3 \\
1 \\
2 \\
2 \\
2\end{array}$ & $\begin{array}{l}23 \\
24 \\
22 \\
23 \\
26\end{array}$ & $\begin{array}{r}67 \\
83 \\
91 \\
106 \\
137\end{array}$ & $\begin{array}{l}5.53 \\
5.54 \\
5.52 \\
5.61 \\
5.57\end{array}$ & $\begin{array}{r}48 \\
60 \\
66 \\
77 \\
100\end{array}$ & $\begin{array}{r}71 \\
84 \\
88 \\
100 \\
126\end{array}$ & 7.34 & 22.7 & 43.4 \\
\hline
\end{tabular}




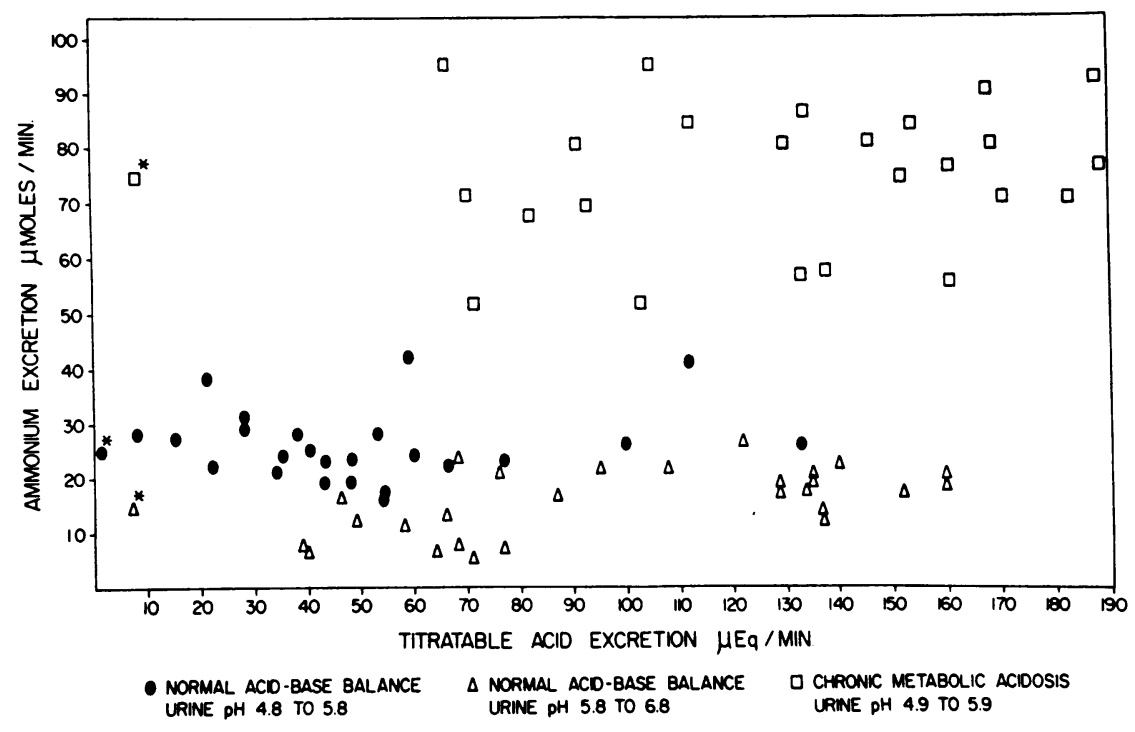

Fig. 1. The EFFECt OF PROGResSive INCREASES IN TItratable ACID EXCRETION UPON THE CONCURRENT RATE OF AMMONIUM EXCRETION.

During the control periods, urine $\mathrm{pH}$ varied between 6.46 and 6.60 and ammonium excretion between 18 and $26 \mu$ moles per minute. Titratable acid contributed only small amounts to total acid excretion. With the subsequent infusion of sodium phosphate, titratable acid excretion increased to $135 \mu \mathrm{Eq}$ per minute, while urine $\mathrm{pH}$ remained essentially constant. As can be seen from the table, the marked rise in titratable acid excretion was without effect on ammonium under these circumstances. Blood $\mathrm{pH}$ and bicarbonate rose moderately during phosphate loading.

The results of all five experiments in which this protocol was followed are shown as triangles in Figure 1. The average of ammonium and titratable acid values during sodium chloride administration is represented by the symbol marked with an asterisk. Urine $\mathrm{pH}$ values were between 5.8 and 6.8 in almost all periods and varied by no more than 0.5 unit in individual experiments. It is apparent from the figure that increases in titratable acid excretion up to $160 \mu \mathrm{Eq}$ per minute had virtually no effect upon the simultaneous excretion of ammonium. Sodium excretion rose in one experiment, fell in one, and remained essentially unchanged in the other three.

TABLE II

The effect of a sodium phosphate infusion upon ammonium excretion

\begin{tabular}{|c|c|c|c|c|c|c|c|c|c|c|c|c|c|}
\hline \multirow[b]{2}{*}{ Time } & \multicolumn{7}{|c|}{ Urine } & \multirow[b]{2}{*}{$\mathrm{pK}_{2}^{\prime}$} & \multirow[b]{2}{*}{$\mathrm{TA}$} & \multirow[b]{2}{*}{$\overline{\mathrm{TA}+\mathrm{NH}_{4}{ }^{+}}$} & \multicolumn{3}{|c|}{ Plasma } \\
\hline & Flow & $\mathrm{Na}$ & $\mathrm{K}$ & $\mathrm{Cl}$ & $\mathrm{NH}_{4}{ }^{+}$ & $\mathbf{P}$ & $\mathrm{pH}$ & & & & $\mathrm{pH}$ & $\mathrm{HCO}_{3}$ & $\overline{\mathrm{pCO}_{2}}$ \\
\hline $\min$ & $m l / \min$ & $\underset{\text { min }}{\text { minoles/ }}$ & $\underset{\text { min }}{\text { mmoles/ }}$ & $\underset{\min }{\min / \mathrm{l} / \mathrm{T}}$ & $\underset{\min }{\mu \text { moles/ }}$ & $\underset{\text { min }}{\mu \text { moles/ }}$ & & & $\underset{\min }{\mu E q /}$ & $\underset{\min }{\mu E q /}$ & & mmoles $/ L$ & $m m H g$ \\
\hline 0 & \multicolumn{10}{|c|}{ Infusion: $\mathrm{NaCl}, 135 \mathrm{mmoles} / \mathrm{L}$ at $6.8 \mathrm{ml} / \mathrm{min}$} & & & \\
\hline $\begin{array}{c}60-70 \\
70-80 \\
80-90 \\
90-100 \\
100-110\end{array}$ & $\begin{array}{l}5.2 \\
7.4 \\
7.0 \\
5.8 \\
5.2\end{array}$ & $\begin{array}{l}442 \\
375 \\
434 \\
505 \\
515\end{array}$ & $\begin{array}{l}73 \\
74 \\
77 \\
84 \\
80\end{array}$ & $\begin{array}{l}511 \\
448 \\
496 \\
632 \\
567\end{array}$ & $\begin{array}{l}25 \\
24 \\
26 \\
19 \\
18\end{array}$ & $\begin{array}{l}14 \\
13 \\
14 \\
18 \\
18\end{array}$ & $\begin{array}{l}6.46 \\
6.47 \\
6.46 \\
6.55 \\
6.60\end{array}$ & $\begin{array}{l}6.80 \\
6.88 \\
6.84 \\
6.80 \\
6.79\end{array}$ & $\begin{array}{l}6 \\
6 \\
7 \\
7 \\
7\end{array}$ & $\begin{array}{l}31 \\
30 \\
33 \\
26 \\
25\end{array}$ & 7.28 & 20.8 & 41.7 \\
\hline 112 & \multicolumn{13}{|c|}{ Infusion : $\mathrm{Na}_{2} \mathrm{HPO}_{4}, 60$ mmoles $/ \mathrm{L} ; \mathrm{NaH}_{2} \mathrm{PO}_{4}, 15$ mmoles $/ \mathrm{L}$; dextrose, $55 \mathrm{mmoles} / \mathrm{L}$ at $6.8 \mathrm{ml} / \mathrm{min}$} \\
\hline $\begin{array}{l}135-145 \\
145-155 \\
155-165 \\
165-175 \\
175-185\end{array}$ & $\begin{array}{l}6.5 \\
7.4 \\
8.0 \\
7.2 \\
7.3\end{array}$ & $\begin{array}{l}559 \\
518 \\
624 \\
691 \\
667\end{array}$ & $\begin{array}{l}107 \\
115 \\
116 \\
122 \\
123\end{array}$ & $\begin{array}{l}371 \\
239 \\
254 \\
266 \\
209\end{array}$ & $\begin{array}{l}19 \\
19 \\
18 \\
18 \\
21\end{array}$ & $\begin{array}{l}227 \\
272 \\
315 \\
353 \\
365\end{array}$ & $\begin{array}{l}6.26 \\
6.42 \\
6.55 \\
6.64 \\
6.63\end{array}$ & $\begin{array}{l}6.79 \\
6.81 \\
6.80 \\
6.78 \\
6.78\end{array}$ & $\begin{array}{l}129 \\
135 \\
134 \\
129 \\
135\end{array}$ & $\begin{array}{l}148 \\
154 \\
152 \\
147 \\
156\end{array}$ & $\begin{array}{l}7.39 \\
7.36 \\
7.36\end{array}$ & $\begin{array}{l}21.1 \\
22.8 \\
23.2\end{array}$ & $\begin{array}{l}36.0 \\
41.5 \\
42.4\end{array}$ \\
\hline
\end{tabular}


TABLE III

The effect of a sodium phosphate infusion upon ammonium excretion

\begin{tabular}{|c|c|c|c|c|c|c|c|c|c|c|c|c|}
\hline \multicolumn{10}{|c|}{ Urine } & \multicolumn{3}{|c|}{ Plasma } \\
\hline Time & Flow & $\mathrm{Na}$ & $\mathrm{K}$ & $\mathrm{Cl}$ & $\mathrm{NH}_{4}{ }^{+}$ & $P$ & $\mathrm{pH}$ & TA & $\mathrm{TA}+\mathrm{NH}_{4}{ }^{+}$ & $\mathrm{pH}$ & $\mathrm{HCO}_{3}$ & $\mathrm{pCO}_{2}$ \\
\hline $\min$ & $\mathrm{ml} / \mathrm{min}$ & $\underset{\min }{\mu \text { moles } /}$ & $\underset{\min }{\mu \text { moles }}$ & $\underset{\mathrm{min}}{\mu \text { moles } /}$ & $\underset{\min }{\text { umoles } /}$ & $\underset{\min }{\mu \text { moles }}$ & & $\underset{\min }{\mu E q /}$ & $\underset{\min }{\mu E q /}$ & & mmoles $/ L$ & $m m \mathrm{Hg}$ \\
\hline 0 & \multicolumn{9}{|c|}{ Infusion: $\mathrm{HCl}, 0.1 \mathrm{~N}$; dextrose, $220 \mathrm{mmoles} / \mathrm{L}$ at $6.8 \mathrm{ml} / \mathrm{min}$} & 7.15 & 9.2 & 27.2 \\
\hline 42 & \multicolumn{12}{|c|}{ Infusion: $\mathrm{Na}_{4} \mathrm{Fe}(\mathrm{CN})_{6}, 31 \mathrm{mmoles} / \mathrm{L}$; dextrose, $72 \mathrm{mmoles} / \mathrm{L}$ at $6.8 \mathrm{ml} / \mathrm{min}$} \\
\hline $\begin{array}{c}60-70 \\
70-80 \\
80-90 \\
90-100 \\
100-110\end{array}$ & $\begin{array}{r}10.4 \\
10.3 \\
9.1 \\
6.7 \\
4.5\end{array}$ & $\begin{array}{l}342 \\
349 \\
319 \\
415 \\
481\end{array}$ & $\begin{array}{l}88 \\
82 \\
68 \\
74 \\
89\end{array}$ & $\begin{array}{r}124 \\
118 \\
62 \\
60 \\
51\end{array}$ & $\begin{array}{r}76 \\
71 \\
72 \\
72 \\
76\end{array}$ & $\begin{array}{l}20 \\
17 \\
17 \\
16 \\
19\end{array}$ & $\begin{array}{l}5.52 \\
5.87 \\
5.63 \\
5.36 \\
5.20\end{array}$ & $\begin{array}{r}12 \\
9 \\
9 \\
9 \\
11\end{array}$ & $\begin{array}{l}88 \\
80 \\
81 \\
81 \\
87\end{array}$ & 7.01 & 6.2 & 28.0 \\
\hline 111 & \multicolumn{12}{|c|}{ Infusion: $\mathrm{Na}_{2} \mathrm{HPO}_{4}, 50$ mmoles $/ \mathrm{L} ; \mathrm{NaH}_{2} \mathrm{PO}_{4}, 25 \mathrm{mmoles} / \mathrm{L}$; dextrose, $28 \mathrm{mmoles} / \mathrm{L}$ at $6.8 \mathrm{ml} / \mathrm{min}$} \\
\hline $\begin{array}{l}135-145 \\
145-155 \\
155-165 \\
165-175 \\
175-185\end{array}$ & $\begin{array}{l}7.1 \\
7.4 \\
7.9 \\
7.4 \\
6.8\end{array}$ & $\begin{array}{l}374 \\
370 \\
393 \\
370 \\
374\end{array}$ & $\begin{array}{l}92 \\
85 \\
75 \\
70 \\
68\end{array}$ & $\begin{array}{l}46 \\
48 \\
46 \\
50 \\
48\end{array}$ & $\begin{array}{l}81 \\
81 \\
75 \\
71 \\
71\end{array}$ & $\begin{array}{l}142 \\
196 \\
225 \\
253 \\
274\end{array}$ & $\begin{array}{l}5.48 \\
5.39 \\
5.23 \\
5.21 \\
5.27\end{array}$ & $\begin{array}{r}91 \\
130 \\
152 \\
171 \\
183\end{array}$ & $\begin{array}{l}172 \\
211 \\
227 \\
242 \\
254\end{array}$ & 7.14 & 6.9 & 20.8 \\
\hline
\end{tabular}

As can be seen from the figure, ammonium excretion was generally higher in the animals with aciduria than in those with more alkaline urine.

Group II. In Table III is shown one of the experiments in which ammonium excretion was enhanced by prior induction of metabolic acidosis. Plasma bicarbonate was lowered further by infusion of $0.1 \mathrm{~N} \mathrm{HCl}$. During the administration of sodium ferrocyanide, urine $\mathrm{pH}$ varied between 5.20 and 5.87 and ammonium excretion between 71 and $76 \mu$ moles per minute. The contribution of titratable acid to total acid excretion was small. As the result of sodium phosphate ( $\mathrm{pH} 7.1$ ) loading, titratable acid excretion rose to $183 \mu \mathrm{Eq}$ per minute, but it is apparent that this was without effect upon the concurrent excretion of ammonium. Urine $\mathrm{pH}$ remained within the narrow range of 5.21 to 5.48 and sodium excretion was essentially constant. Blood bicarbonate did not vary throughout the experiment, but $\mathrm{pH}$ rose and $\mathrm{pCO}_{2}$ fell.

The results of the five experiments in this group are shown as squares in Figure 1. The symbol representing the average ammonium and titratable acid values during sodium ferrocyanide infusion is marked by an asterisk. Ammonium excretion was greater in this group than in Group I because of the stimulus of chronic metabolic acidosis. The wide spread in rates of ammonium excretion in the acidotic animals is not the result of differences in urine $\mathrm{pH}$, since this varied by no more than 0.7 unit in individual experiments. It is, rather, related to differences in the duration of ammonium chloride ingestion. For example, the five points of lowest ammonium excretion are from the experiment in which ammonium chloride was fed for the shortest period of time. It is apparent, however, that increases in titratable acid up to $190 \mu \mathrm{Eq}$ per minute had no significant effect upon the rate of ammonium excretion. Sodium excretion remained essentially constant in all five experiments.

\section{DISCUSSION}

The present experimental observations demonstrate that, under conditions of relatively constant urine $\mathrm{pH}$, progressive increases in titratable acid excretion can take place without having any significant effect upon the concurrent rate of ammonium excretion. This was found to be true in the presence of normal acid-base balance and also in chronic metabolic acidosis with markedly augmented rates of ammonium excretion. This dissociation of ammonium from titratable acid excretion is consistent with the view that $\mathrm{NH}_{3}$ diffuses passively into an acid tubular fluid where it is "trapped" by conversion to $\mathrm{NH}_{4}{ }^{+}$(4). The rate at which this physicochemical process proceeds depends primarily upon the $\mathrm{pH}$ gradient between tubule cell and lumen and should be independent of all changes in composition of the tubule fluid other than that of $\mathrm{pH}(4)$. It therefore follows that the addition of large amounts of buffer 
to the tubular fluid and the associated acceleration of $\mathrm{Na}^{+}-\mathrm{H}^{+}$exchange should not influence ammonium excretion. However, the results of these experiments are also compatible with the hypothesis that $\mathrm{NH}_{4}^{+}$gains access to the urine by an independent $\mathrm{Na}^{+}-\mathrm{NH}_{4}{ }^{+}$exchange mechanism (9, $16)$, and therefore do not provide critical information concerning the intimate nature of ammonium transport into the urine.

It has been demonstrated repeatedly that ammonium excretion in man and dog is inversely related to urine $\mathrm{pH}(1,4,5,17)$, a fact which is most readily explained by the passive diffusion theory. According to the physical laws governing such a process, ammonium excretion should increase tenfold with each unit fall in urine $\mathrm{pH}$ if the tubular cell membrane is freely permeable to $\mathrm{NH}_{3}$ and completely impermeable to $\mathrm{NH}_{4}^{+}(4,6)$. Stated in another way, there should be a linear relationship between urine $\mathrm{pH}$ and ammonium excretion when the latter is plotted logarithmically, and the regression coefficient defining the rate of change of $\log$ ammonium excretion per unit fall in urine $\mathrm{pH}$ should be -1.0 (6). The experimentally observed relationship in man and $\operatorname{dog}$ is indeed linear but the calculated regression coefficient is considerably less than unity $(3,4)$. In order to account for this discrepancy within the context of the diffusion hypothesis, it has been postulated that the rate of intracellular ammonia production limits ammonium excretion in acid urine and is insufficient for an equilibrium state to be achieved (4). This postulate is based on the observation that ammonium excretion varies with urine flow in the alkaline but not in the acid range of urine $\mathrm{pH}(4)$. As an alternate explanation, it seems reasonable that the availability or rate of diffusion of hydrogen ions into the tubular fluid might play a significant regulatory role in ammonium excretion, particularly in acid urine, since $\mathrm{H}^{+}$is necessary for the conversion of $\mathrm{NH}_{3}$ to $\mathrm{NH}_{4}{ }^{+}$prior to excretion. However, the present studies show that large increases in hydrogen ion excretion can take place in both alkaline and acid urine at a time when ammonium excretion is already maximal for the urine $\mathrm{pH}$. This suggests that, in experimental situations where only endogenous amounts of buffer are present, hydrogen ions are available in excess and therefore do not constitute a limiting factor in ammonium excre- tion. Indeed, the present experimental observations indicate that the process regulating ammonium excretion in the dog may be largely independent of total hydrogen ion excretion and those factors that determine the magnitude of the $\mathrm{Na}^{+}-\mathrm{H}^{+}$exchange mechanism.

\section{SUMMARY}

The relationship between ammonium and titratable acid excretion has been studied in dogs under conditions of relatively constant urine $\mathrm{pH}$. It was found that progressive increases in titratable acid excretion due to sodium phosphate loading had no significant effect upon ammonium excretion in either normal or chronically acidotic animals. This dissociation of ammonium from titratable acid excretion is consistent with the view that ammonia accumulates in the urine by passive diffusion, since this process depends primarily upon the $\mathrm{pH}$ gradient between tubular cell and lumen and should be independent of all changes in composition of the tubular fluid other than that of $\mathrm{pH}$. However, an independent $\mathrm{Na}^{+}-\mathrm{NH}_{4}{ }^{+}$exchange mechanism can also account for the present observations and, therefore, conclusions cannot be drawn from these experiments concerning the intimate nature of the tubular mechanism for ammonium excretion.

The finding that large increases in titratable acid excretion can take place without affecting urinary ammonium suggests that, in experimental situations where only endogenous amounts of buffer are present, hydrogen ions are available in excess and do not constitute a limiting factor in ammonium excretion. It appears, rather, that ammonium excretion in the dog may be largely independent of total hydrogen ion excretion and those factors that determine the magnitude of the $\mathrm{Na}^{+}-\mathrm{H}^{+}$exchange mechanism.

\section{REFERENCES}

1. Pitts, R. F. Renal excretion of acid. Fed. Proc. 1948, 7, 418.

2. Pitts, R. F., and Lotspeich, W. D. Factors governing the rate of excretion of titratable acid in the dog. Amer. J. Physiol. 1946, 147, 481.

3. Clarke, E., Evans, B. M., MacIntyre, I., and Milne, M. D. Acidosis in experimental electrolyte depletion. Clin. Sci. 1955, 14, 421.

4. Orloff. T., and Berliner, R. W. The mechanism of 
the excretion of ammonia in the dog. J. clin. Invest. 1956, 35, 223.

5. Schwartz, W. B., Jenson, R. L., and Relman, A. S. Acidification of the urine and increased ammonium excretion without change in acid-base equilibrium: Sodium reabsorption as a stimulus to the acidifying process. J. clin. Invest. 1955, 34, 673.

6. Milne, M. D., Scribner, B. H., and Crawford, M. A. Non-ionic diffusion and the excretion of weak acids and bases. Amer. J. Med. 1958, 24, 709.

7. Hendrix, B. M., and Sanders, J. P. The effect of injections of sodium phosphates and sodium hippurate upon the excretion of acid and ammonia by the kidney. J. biol. Chem. 1923, 58, 503.

8. Pitts, R. F., and Alexander, R. S. The renal reabsorptive mechanism for inorganic phosphate in normal and acidotic dogs. Amer. J. Physiol. 1944, 142, 648.

9. Rector, F. C., Jr., Seldin, D. W., Roberts, A. D., Jr., and Copenhaver, J. H. Relation of ammonia excretion to urine pH. Amer. J. Physiol. 1954, 179, 353.

10. Seldin, D. W., Teng, H. C., and Rector, F. C., Jr. Ammonia excretion and renal glutaminase activity during administration of strong acid and buffer acid. Proc. Soc. exp. Biol. (N. Y.) 1957, 94, 366.
11. Van Slyke, D. D., and Neill, J. M. The determination of gases in blood and other solutions by vacuum extraction and manometric measurement. 1 . J. biol. Chem. 1924, 61, 523.

12. Folin, O., and Bell, R. D. Applications of a new reagent for the separation of ammonia. 1. The colorimetric determination of ammonia in urine. J. biol. Chem. 1917, 29, 329.

13. Fiske, C. H., and Subbarow, Y. The colorimetric determination of phosphorus. J. biol. Chem. 1925, $66,375$.

14. Sanderson, P. H. Potentiometric determination of chloride in biological fluids. Biochem. J. 1952, 52, 502.

15. Schwartz, W. B., Bank, N., and Cutler, R. W. P. The influence of urinary ionic strength on phosphate $\mathrm{pK}_{2}^{\prime}$ and the determination of titratable acid. J. clin. Invest. 1959, 38, 347.

16. Ullrich, K. J., Hilger, H. H., and Klümper, J. D. Sekretion von Ammoniumionen in den Sammelrohren der Säugetierniere. Pflüg. Arch. ges. Physiol. 1958, 267, 244.

17. Epstein, F. H., Kleeman, C. R., Lamdin, E., and Rubini, M. E. Studies of the antidiuresis of quiet standing: Observations upon electrolyte and acid-base excretion during sulfate diuresis. J. clin. Invest. 1956, 35, 308. 